\title{
RECENT PROGRESS IN OBSTETRICS.
}

BY W. L. RICHARDSON, M. D.

Treatment of Pregnancy complicated with Cancerous Disease of the Genital Canal. - In the last volume of the Transactions of the Obstetrical Society of London (vol. xx., 1878), Dr. G. Ernest Herman has a most valuable article on this serious complication of pregnancy. It is based upon a careful study of one hundred and eighty cases. The general conclusions with which the writer closes the article are as follows : -

(1.) That whatever influence cancer of the uterus may have upon conception is adverse to its occurrence.

(2.) That cancer of the uterus tends to produce the intra-uterine death and premature expulsion of the fotus.

(3.) That the growth of cancer of the uterus is, as a rule, accelerated during pregnancy.

(4.) That with cancerous disease affecting the whole circumference of the os uteri labor may be quick and easy, and the patient may recover well, and live for months afterwards.

(5.) That when delivery under such conditions is accomplished by natural efforts, expansion of the cervix usually takes place by fissuring.

(6.) That this fissuring does not usually augment the risk to the mother.

(7.) That imitation of this natural process, by making incisions, neither increases the danger at the time nor accelerates the progress of the disease subsequently, and that it often greatly facilitates delivery.

(8.) That the cases in which the cancer forms a tumor of great size or hardness are the ones in which delivery by natural efforts will not take place.

(9.) That where the above characters are absent, no definite criteria can be drawn from the local conditions by which to foretell the behavior of the cervix uteri during labor.

(10.) That where delivery of a living child per vias naturales is impossible, such limited experience as we have shows that there is but little difference, as to risk to the mother, between craniotomy and Cosarean section.

He also draws the following conclusions as to proper practice to be adopted in dealing with such cases :-

(1.) That where it is possible to remove the disease, either during pregnancy or at the time of labor, it ought to be done.

(2.) That where this cannot be done the safety of the mother is best consulted by bringing the pregnancy to an end as soon as possible.

(3.) That, when labor has actually come on, expansion of the os uteri 
should be aided by making numerous small incisions in its circumference.

(4.) That dilatation of the os uteri being in progress, if uterine action should be deficient, and it becomes necessary to accelerate labor, the use of the forceps is, as a rule, better than version.

(5.) That when dilatation of the cervix cannot take place, even after incisions have been made, either from rigidity or magnitude of the tumor, Cæsarean section should be performed.

Comparative Danger of First Labors. - Dr. J. G. Swayne has recently read before a branch of the British Medical Association a valuable paper, ${ }^{1}$ in which he endeavors to answer the question whether first labors are more dangerous than others. His opinions are based upon a careful examination of ten hundred and twenty-two cases which have occurred in his own private practice. Of these two hundred and thirtyone were primiparæ, and seven hundred and ninety-one multiparæ. No mother died among the former, while five of the multiparæ were lost. The causes of deaths were as follows: In one it was heart disease, which existed previous to the labor, which became worse after delivery, and terminated fatally on the twenty-seventh day; in another it was puerperal scarlatina, proving fatal on the fifth day; in another ruptured uterus; in another pneumonia, commencing two days before labor, and ending in death six days afterwards; and in the fifth convulsions, which proved fatal a few hours after delivery. Thus the proportion of maternal deaths in the multiparæ was about one in one hundred and fifty-eight, whilst in the primiparæ there was no death in two hundred and thirty-one cases, a difference greatly to the advantage of first labors.

As regards the children, however, the difference was slightly the other way: in the two hundred and thirty-one first labors the deaths of eighteen infants are recorded, or about 7.8 per cent., whilst in the seven hundred and ninety-one multiparæ forty-seven infants died, or about 5.9 per cent.

A careful examination of the cases in detail show some interesting facts which characterize first from other labors. In primiparæ, owing to a prolonged first stage, the uterus is more exhausted, and forceps are more frequently demanded. Thus in two hundred and thirty-one primiparæ Dr. Swayne used forceps fifty-two times, or nearly one in four, whilst in the seven hundred and ninety-one multiparæ they were employed only twenty-five times, or nearly one in thirty-one. Hence come a larger number of deaths of infants from the pressure during the prolonged labor. In first labors the rigidity of the soft parts of the mother gives rise to an increased danger in cases of presentations of the inferior extremities. In the two hundred and thirty-one primi-

1 Obstetrical Journal of Great Britain, May, 1879. 
paræ there were six breech presentations; in four of which the child was still-born, whereas in the seven hundred and ninety-one multiparæ there were fourteen such cases, and only two children lost. Among the multiparæ the greatest cause of infant mortality was premature birth, from which cause there were eighteen deaths ; among the primiparæ there were only three. Post-partum hæmorrhage occurred about equally in both classes, but the amount of blood lost was far greater in the multiparæ. There were eleven cases of twins among the multiparæ, and only one among the primiparæ. There is unquestionably much greater suffering among primiparæ than among multiparæ; on the other hand, the former are, as a rule, younger and in better health and stronger. Rupture of the uterus occurs much more frequently among multiparæ. Dr. Swayne closes his paper with the conclusion that first labors are less dangerous than others to the mother, but slightly more so to the infant.

Value of the Expression Method in Head Presentation. - Professor Bidder (St. Petersburg) believes ${ }^{1}$ strongly in the value of this method of effecting a delivery, and considers that the method has fallen into disrepute only because practitioners have not properly used it. In cases where there is simply a lack of expulsive force he thinks this procedure should take the place of the forceps. It should be used, however, only during the second stage. The hand should be applied on the upper part of the foetus, and the pressure should be directed in such a way only as to be in the line of the foetal axis. The hand should first be properly applied, and then the pressure should be steady, great care being taken that no friction whatever is used. The writer gives an account of eighty-one cases in which this method was successfully adopted. Of the mothers, thirty-four made a perfectly normal convalescence; there were slight deviations from a normal recovery in the case of thirty-eight, while seven became very sick, and two cases terminated fatally. By way of comparison he cites the record of seventy-five simple forceps cases. In all the forceps were applied when the head was low down or on the perinæum. Of these thirteen made a normal convalescence; thirty-four were slightly ill, twenty seriously, and eight died. This method of procedure can be resorted to as soon as the head has emerged from the os and the membranes are ruptured. It is not liable to cause any inflammatory condition of the uterus, and is, in his opinion, less apt to give rise to septicæmia than in cases where forceps are used, inasmuch as there is a less liability to any injury of the soft parts.

Causes of Sudden Death in Puerperal Women. - At the last meeting of the American Medical Association, Prof. Edward W. Jenks (Detroit) read a paper in which he discussed at length the various causes

1 Zeitschrift für Geburtshülfe und Gynäkologie, iii. 2, 241. 
which give rise to sudden death in puerperal women. These causes he considered due to lesions of the circulatory, the respiratory, or the nervous system, or to puerperal septicæmia. The latter cause is especially prominent, since many lesions of the various systems mentioned owe their origin to a septic poisoning. Of the divers valvular lesions, mitral stenosis is by far the most dangerous. Endocarditis, old or new, if existing in a woman at the beginning of pregnancy, is extremely liable to be rekindled by the changed condition of the blood during pregnancy, and the result is ulcerative endocarditis. Arteritis is a very rare cause of sudden death, while phlebitis is a very common one. The introduction of air into the uterine sinuses is a most certain cause of sudden death. Any uterine relaxation will leave the mouths of the uterine vessels open; air enters, and the next uterine contraction may force it into the venous circulation. While this is almost a certain cause of death, it is, fortunately, a very rare one. Formerly puerperal eclampsia was a frequent cause of sudden death, but so much has of late years been learned as regards the nature, origin, and treatment of this disease that the death-rate has been reduced from thirty-two to fourteen per cent. during the last twenty years.

Ovarian Pain in Pregnant Women. - Dr. Budin ${ }^{1}$ calls attention to a vivid pain sometimes produced during the latter months of pregnancy and during labor by a very moderate amount of pressure made on the abdomen in the vicinity of a line drawn from the umbilicus to the anterior-superior spine of the ileum, sometimes a little above and sometimes below this line, and at a distance varying from ten to fifteen centimetres from the umbilicus. The pain is occasionally so sharp as to cause exclamations, and even to make the tears start from the eyes. At the seat of this pain, which never occurs spontaneously, a movable body may be felt, resembling in shape and size the ovary. Its presence is most usually felt on the left side, the existence of some resisting surface - usually the back of the fotus - being necessary in order for the body to be felt and the pain to be excited. In some cases this can be done only during the contraction of the uterus. Dr. Budin thinks it possible that this "ovarian pain" has been confounded with a certain form of neuralgia, which several authors have termed rheumatism of the uterus, and with the pain sometimes caused by the pressure of the head on the uterine wall. At times it is very easy to distinguish also the round ligament, but pressure thereon causes no pain. None of the patients in whom this tenderness has been discovered were hysterical.

1 Progrès médicale, ix.; Medical Times and Gazette, April 26, 1879. 